\title{
'There are worse places than Dalmuir!' Glaswegian Riveters on the Clyde and the Copperbelt
}

\author{
Duncan Money
}

Text version of my article that was published in Labour History Review, 80, 3 (2015), pp. 273-92. http://dx.doi.org/10.3828/lhr.2015.12

This article follows the fortunes of a group of riveters who moved, briefly, from the Clyde to the Copperbelt to work on construction at the newly opened copper mines in the region in 1930. Escaping from Depression-era Glasgow, these volatile riveters clashed with hard-bitten American mine managers over wages, self-respect and the colour bar in southern Africa, events best understood within a framework of the transnational world of white labour. The history of labour migration in colonial Africa has been studied almost exclusively in terms of African labour yet large numbers of people arrived from outside the continent to work on the mines in central and southern Africa. Although only a sliver of these wider population flows, the riveters provide a snapshot in the wider British labour movement and movements of white migrants during this period. This article argues that their experiences illustrate the curious, influential politics of 'white labourism' where political radicalism and industrial militancy where intricately linked to white domination and racial segregation. Drawing on records from the mining companies, it will be demonstrated that these men saw themselves as militant representatives of an international working class, but one strictly delineated on racial lines.

It should have been apparent to the management at Roan Antelope Mine that the recruitment of thirtyone riveters from the Clyde to work on construction might be a bad idea before the men ever set foot on the Copperbelt in Northern Rhodesia (now Zambia) in October 1930. Efforts to get some of the men to leave a pub at Tilbury docks and board the imminently departing ship to Cape Town had almost sparked a brawl. A brawl did halt the journey through Southern Rhodesia after one of the riveters, who had come off worst, crawled under the train and refused to come out. One man inexplicably had a passport in another man's name and all the men constantly used language so foul that it shocked even the ex-soldier escorting them. ${ }^{1}$

\footnotetext{
${ }^{1}$ Zambia Consolidated Copper Mines, Ndola (hereafter ZCCM)16.2.4B, Telegram from D.C. D'Eath to G.A. Berry, [undated] and Report on arrival of second group of Scotch riveters, T. Weatherall, 11 February 1931
} 
This article follows the chaotic journey, brief stay and abrupt departure of two groups of riveters recruited from the Clyde to mines on the Copperbelt in 1930. The experiences of these two groups are well-documented in files at the Zambia Consolidated Copper Mines Archive in Ndola, Zambia and contemporary newspaper reports, the two main sources for this article. The mining companies paid close attention to the recruitment of skilled white labour and to the activities of their white employees on and off the job, leaving a rich historical record which includes some accounts from the workers themselves.

The close, even obsessive, interest the mining companies had in their white workforce has not been reflected in subsequent historical writing. The academic work that has been done on labour migration to the Copperbelt mines has primarily examined African labour migration, with a particular focus on the shift from a migrant workforce to an urbanised 'stabilised' workforce. ${ }^{2}$ Yet the Copperbelt also attracted thousands of transient white workers from mining and industrial centres around the world, who have been 'hardly looked at... at all' by academics according to Ian Phimister. ${ }^{3}$ Although small in number, these riveters are worth examining as they were part of wider international flow of white labour during this period and provide a useful case study for looking at the literature on crew cultures and on white labourism.

James Belich identified crews as 'the shock troops of booms' in this case the copper boom, with their own distinctive culture and occupying a world of 'the camp sector' ${ }^{4}$ Belich initially defined crews with reference to sailors, who typically regularly changed ships during their working life, but each ship and its crew would be similar and familiar. The culture of these crews extended into other extractive industries. ${ }^{5}$ Similarly, the workplace of riveters was constantly changing, as construction of one ship

\footnotetext{
${ }^{2}$ Some notable works in this vein include Elena L. Berger, Labour, Race, and Colonial Rule: The Copperbelt from 1924 to Independence (Oxford, 1974), Charles Perrings, Black Mineworkers in Central Africa: Industrial strategies and the evolution of an African proletariat in the Copperbelt 1911-41 (London, 1979) and Jane L. Parpart, Labor and Capital on the African Copperbelt (Philadelphia, 1983).

${ }^{3}$ Ian Phimister, 'Workers in Wonderland? White Miners and the Northern Rhodesian Copperbelt, 1946-1962', South African Historical Journal, 63, 2 (2011), 191. In this article, the terms 'European' and 'white' refer to people of European descent. The terms are used interchangeably in contemporary documents.

${ }^{4}$ James Belich, Replenishing the Earth: The Settler Revolution and the Rise of the Anglo-World, 1783-1939 (Oxford, 2009), 323-24.

${ }^{5}$ James Belich, Making Peoples: A History of New Zealanders from Polynesian Settlement to the End of the Nineteenth Century (Auckland, 1996), 428-30.
} 
finished they would move on to another job, yet remained the same. Moreover, as a group which was 'mobile, male and prone to binge and to hit each other' the Glaswegian riveters who arrived on the Copperbelt in 1930 seem like the archetype. ${ }^{6}$ More importantly, riveters on the Clyde, at this time, did not work as individuals on the job but as a gang and they were paid collectively. ${ }^{7}$ Belich has argued that crews were associated with persistent individualism and the jobs they undertook did not involve collective struggle. ${ }^{8}$ However, as will be seen, these Glaswegian men had very firm ideas about their place in the trade union movement and about the central importance of collective struggle.

These riveters can be seen as a kind of transition from 'crew culture' to 'white labourism'. Indeed, Jonathan Hyslop - who coined the term - draws on the concept of crew culture in his original article on the subject. ${ }^{9}$ Hyslop uses the term white labourism to capture the intermingling of political radicalism and industrial militancy with white domination and racial segregation in the international labour movement. Hsylop identifies an international white working class not composed of discrete national entities and dominated by an ideology of white labourism generated by flows of white migrants around the empire. More recently, William Kenefick has argued white labourism did not go unchallenged within the labour movement in South Africa, and that there was a determined challenge to these ideas disproportionately influenced by radical Scottish migrants. ${ }^{10}$ Following the fortunes of these Glaswegian riveters, who certainly fit the bill of radical Scottish migrants, tends to support Hyslop's reply to Kenefick that Scottish workers played an active role in generating racialized labour protectionism in southern Africa. ${ }^{11}$

Hsylop locates the highpoint of white labourism ideology and the migrant flows that underpinned in the years prior to the First World War but the riveters were committed exponents of these ideas, suggesting

\footnotetext{
${ }^{6}$ James Belich, Paradise Reforged: A history of the New Zealanders from the 1880s to the year 2000 (Auckland, 2001), 19.

${ }^{7}$ Alan MacKinlay and John Hampton, 'Making Men: Working for John Brown's between the Wars’, Oral History, 19, 1 (1991), 25-6.

${ }^{8}$ Belich, Making Peoples, 433.

${ }^{9}$ Jonathan Hyslop, 'The Imperial Working Class Makes Itself 'White': White Labourism in Britain, Australia, and South Africa Before the First World War', Journal of Historical Sociology, 12, 4 (1999), 410.

${ }^{10}$ William Kenefick, "Confronting White Labourism: Socialism, Syndicalism, and the Role of the Scottish Radical Left in South Africa before 1914”, International Review of Social History, 22 (2010), 29-62.

${ }^{11}$ Jonathan Hyslop, 'Scottish Labour, Race, and Southern African Empire c.1880-1922: A Reply to Kenefick', International Review of Social History, 55 (2010), 63-81.
} 
they had enduring resonances and continued to circulate internationally. Studies of Scottish migration have similarly overlooked the period after 1914, even though as Nicholas Evans has pointed out 'the Scottish worker... functioned within an international labour market' at this time and often sought work abroad for short periods, even for as brief as a single season. ${ }^{12}$ Few stayed as briefly as these riveters, yet the very fact the riveters readily sought work in such a distant spot, at least distant from Glasgow, and did not see this as a particularly unusual thing to do suggest that they did see themselves as operating in an international labour market.

Part of operating in this labour market meant firm adherence to the traditions of the trade and the traditions of the international trade union movement, which white workers brought to the Copperbelt along with their industrial skills. Lucien van der Walt has noted that across southern Africa 'the politics of white workers were, unsurprisingly, deeply shaped by foreign models' ${ }^{13}$ This was particularly the case on the Copperbelt, as virtually the entire white workforce came from outside the colony.

This international influence includes the formulation and implementation of racially exclusive working practices - generally known as the colour bar - which prevented African workers from moving into semi-skilled and skilled jobs. This has generally been seen as something that arose on the Copperbelt as a result of the specific colonial situation there and was abnormal in the wider history of the trade union movement. ${ }^{14}$ Yet the Glaswegian riveters who arrived on the Copperbelt had no experience of working in colonial Africa and, as will be seen, their opposition to perceived exploitation by the mine management was bound up with support for racist working practices. These riveters - usually nicknamed the 'black squad' - were firmly in favour of the colour bar. ${ }^{15}$ This suggests that these ideas were transnational rather than local in origin and were deeply embedded among some sections of the British working class.

\section{Copper companies on the Copperbelt}

${ }^{12}$ Nicholas J. Evans, 'The Emigration of Skilled Male Workers from Clydeside during the Interwar Period', International Journal of Maritime History, 28, 1 (2006), 256, 258.

${ }^{13}$ Lucien van der Walt, 'The First Globalisation and Transnational Labour Activism in Southern Africa: White Labourism, the IWW, and the ICU, 1904-1934', African Studies, 66, 2-3 (2007), 228.

14 This has been a theme in the literature since at least Julius Lewin, The Colour Bar in the Copper Belt, (Johannesburg, 1941) and the general trend since then has been to attribute racial segregation on the Copperbelt to the colonial situation and influence of South African mineworkers.

15 The name reflected the perceived toughness of their work, see MacKinlay and Hampton, 'Making Ships, Making Men', 27. 
The vast scale of copper deposits along Northern Rhodesia's border with Belgian Congo had become evident in the 1920s, when the smattering of prospectors were supplanted by the resources of international mining companies. Claims and prospecting rights in the area which became known as the Copperbelt were held by a complex patchwork of companies, a picture which was rapidly transformed as they were snapped up, merged, consolidated and reorganized. ${ }^{16}$ By 1930, two mining companies had divided up the Copperbelt between them, establishing themselves in a dominant position which would remain unaltered until the late $1960 \mathrm{~s} .{ }^{17}$

These two companies were the Rhodesian Selection Trust (RST), based in London but primarily staffed and financed by Americans, which operated Roan Antelope Mine and Rhodesian Anglo American (RAA), which was neither Anglo nor American but a subsidiary of the South African mining conglomerate Anglo American, and operated Nkana Mine. The speed of the both company's actions had been motivated by a keen awareness of the riches they now possessed. Both pressed forward to bring the mines to production. Following developments in other mining regions elsewhere in the world, the first production techniques on the Copperbelt were designed to minimise the use of unskilled labour, which in the colonial context meant Africans. ${ }^{18}$ Rapid construction and underground development therefore required a large amount of skilled and semi-skilled labour.

The companies turned to mining and industrial centres around the world to meet their demands for more skilled labour, a move partly prompted by the fact that Northern Rhodesia's tiny settler population was largely bereft of industrial skill and experience. Initially, for instance, almost all drilling jobs at Roan Antelope were done by Americans, though these drillers were expensive and the companies successfully broadened their field of recruitment. ${ }^{19}$ Even with a very high turnover of labour, for both European and African workers, direct European employment at Roan Antelope rose from 269 in January 1929 to 916

\footnotetext{
${ }^{16}$ An overview of the complex process of company formation and consolidation can be found in B.W.E. Alford and C.E. Harvey, 'Copperbelt Merger: The Formation of the Rhokana Corporation, 1930-1932', The Business History Review, 54, 3 (1980), 330-358 and Simon Cunningham, The Copper Industry in Zambia: Foreign Mining Companies in a Developing Country (New York, 1981), 45-85.

${ }^{17}$ Larry Butler, Copper Empire: mining and the colonial state in Northern Rhodesia, c. 1930-64 (Basingstoke, 2007), 17.

${ }^{18}$ Perrings, Central Africa, 95. Berger, Labour, 12.

${ }^{19}$ Zambia National Archives, Lusaka [hereafter ZNA], RC/360, Selection Trust Limited: Schedule of staff and employees in South Africa as at December 1927. Virtually all drillers listed in this 1927 employee list are
} American. 
in September. The focus of recruitment and the mines' labour requirements are illustrated by the fact that African employment rose by a much lower proportion, from 3,144 to 4,438, during the same period. ${ }^{20}$ Hundreds of transient European workers also arrived to work for contractors at this time and the mine's secretary estimated the European workforce peaked at around 2,000. ${ }^{21}$

The wide field of recruitment also reflected the international connections and orientation of these companies, so when riveters were urgently required for the construction of surface plants in July 1930, the mine management did not look locally or regionally, but sought workers 'from Scotch shipyards only'. Wages and working conditions were fixed with explicit reference to other mining regions, as these were the areas the Copperbelt mines competed with for labour. In this case, the riveters were to be paid 25/6 per eight hour shift with 'all other terms similar to Cumberland Miners' ${ }^{22}$

Both RST and RAA were well-positioned to carry out international recruitment as many of their key personnel had strong links to mining regions elsewhere in the world. RST's chairman Alfred Chester Beatty had already enjoyed an extraordinarily successful career as a mining engineer in the United States before the Copperbelt caught his attention. ${ }^{23}$ Beatty utilised his North American connections to staff the upper echelons of Roan Antelope with American mining engineers. London-based managing director Arthur Storke joined RST from Climax Mine in Colorado while on the Copperbelt Roan Antelope's general manager David Irwin has been recruited from Copper Queen Mine in Arizona, where he had been general superintendent. Irwin's general superintendent at Roan Antelope was the American mining engineer Robert Peterson. ${ }^{24}$

\footnotetext{
${ }^{20}$ Selection Trust Archives, London [hereafter ST], G/51, Progress report for three months ended March $31^{\text {st }} 1929$, Progress report for three months ended September $30^{\text {th }} 1930$. African miners were also specifically recruited from outside Northern Rhodesia in early 1930 due to the perceived lack of skill among African workers in the colony, see F. Spearpoint, 'The African Native and the Rhodesian Copper Mines', Journal of the Royal African Society, 36, 144 (1937), 8-9.

${ }^{21}$ Lucy Pope Cullen, Beyond the Smoke that Thunders (New York, 1940), 69.

${ }^{22}$ ZCCM 16.2.4B, Telegram from General Manager, Roan Antelope to Selection Trust, London, 3 July 1930.

${ }^{23}$ John Phillips, 'Alfred Chester Beatty: Mining Engineer, Financier, and Entrepreneur, 1898-1950', in Raymond Dumett (ed.), Mining Tycoons in the Age of Empire, 1870-1945: Entrepreneurship, High Finance, Politics and Territorial Expansion (Farnham, 2009), 217-220.

24 'Arthur Ditchfield Storke', Transactions of the Institution of Mining and Metallurgy, 59 ${ }^{\text {th }}$ Session 1949-50, Vol. LIX, 530. ST, G/51, Letter from D.C. D’Eath to all shareholders, 10 September 1928.
} 
Anglo American were, at least in this period, firm believers in keeping things within the family, and the top job of RAA managing director went to Leslie Pollak, brother-in-law of Anglo American's founder Ernest Oppenheimer. However, Anglo American had little previous experience in copper mining and, as Oppenheimer himself noted in 1936, they 'were induced to follow the American advice because a large part of the funds required [for RAA] were to be supplied by America'. ${ }^{25}$ Anglo American therefore drew on the resources of one of their main American shareholders, the Newmont Mining Company. Newmont seconded one of their senior staff, Harold Munroe, to become RAA's consulting engineer and their connections may also have facilitated the recruitment of Arno Winther from Anna Beaver Mine, Oklahoma to become general manager at Nkana. ${ }^{26}$ Even more key to the company's operations was geologist Dr Austen Bancroft, who had been recruited from the Granby Consolidated Mining, Smelting and Power Company in British Columbia. ${ }^{27}$ Bancroft similarly used his connections to the Canadian mining industry to help fill the ranks of the senior staff on the mine.

Many aspects of life in the Copperbelt mining camps would not have been unusual to mine managers coming from the United States or South Africa, including racial segregation. A legislative colour bar had been in place on the South African Rand since the 1890s and a de facto colour bar was the norm at many American copper mines. ${ }^{28}$ Copper Queen Mine - where Irwin had previously worked - was located in Bisbee, Arizona, the self-proclaimed 'white man's camp' where even non-Anglo whites, such as Italians, were in a subordinate economic and social position. ${ }^{29}$

\section{Riveters and riveting on the Clyde}

Riveters, who, along with platers and caulkers, were also known as boilermakers, had the unenviable job of securing plates and beams onto the structure of a ship using hot metal rivets. This was a tough, predominately manual and dangerous job, and earned riveters a reputation for a 'fierce, reckless

\footnotetext{
${ }^{25}$ Theodore Gregory, Ernest Oppenheimer and Economic Development in Southern Africa (Oxford, 1962), 390.

${ }^{26}$ Gregory, Ernest Oppenheimer, 411, 417. Winther also had 20 years' experience in copper mining in Utah and Peru, see 'Obituary - Arno S. Winther', Proceedings of the Mining and Metallurgical Society of America, Volumes XLI-XLII (New York, 1949), 64.

${ }^{27}$ J.A. Bancroft, Mining in Northern Rhodesia: A chronicle of mineral exploration and mining development (London, 1962), 10.

${ }^{28}$ Elaine Katz, 'White Workers' Grievances and the Industrial Colour Bar, 1902-1913', South African Journal of Economics, 42, 2 (1974), 145-47.

${ }^{29}$ Phylis Cancilla Martinelli, Undermining Race: Ethnic Identities in Arizona Copper Camps, 1880-1920 (Tucson, 2009), 6, 102-32.
} 
combativity normally held in reserve for any personal slight or affront to the trade's behavioural norms'. ${ }^{30}$ The riveter's experience on the Copperbelt suggests such a reputation was well-deserved. Importantly, riveters had to be able to cope with considerable variation in ship's structures, and this gave them transferable skills in construction.

The other reputation of Glaswegian riveters was that they were exceptionally skilled and Evans has noted that overseas recruitment was often specifically targeted at key industrial workers from the Clyde. ${ }^{31}$ It is perhaps unsurprising, then, that RST sought riveters only from 'Scotch shipyards' and engaged the services of a Glasgow labour recruiter, George Berry, to find thirty-one riveters for construction work. Those men considered by Berry and eventually engaged all had very similar backgrounds: virtually all them were in their late 20 s, mostly single, had around 10 years' experience in shipyards and lived along Dumbarton Road, from Dalmuir to Scotstoun. Several were practically neighbours. Most were unemployed and some already had experience working elsewhere in the world. ${ }^{32}$

It is easy to see why Berry quickly found eager recruits to work at a mine in a territory which few of the men had ever heard of. By the interwar years, Glasgow, the second city of the empire, was a city that had seen better days. The shipbuilding industry in particular, was hit by a sharp slump in 1922-23, followed by another slump in 1926. The typical response of Clyde shipbuilders in this period was to close yards and lay off workers until demand improved, and several yards closed between 1926 and 1930. ${ }^{33}$ The response of many people was to simply leave in search of a better life elsewhere, or even temporarily to find work, and there were high levels of emigration between 1921 and $1931 .{ }^{34}$ The River Clyde represented both 'a repeated reminder of connections with the wider world' and 'a high way to empire' to escape grinding poverty. ${ }^{35}$

\footnotetext{
${ }^{30}$ This paragraph draws heavily from MacKinlay and Hampton, 'Making Ships, Making Men', 26-27.

${ }^{31}$ Evans, 'Emigration of skilled male workers', 259.

${ }^{32}$ ZCCM 16.2.4B, List of possible rivetters for Roan Antelope Copper Mines, 14 July 1930, letter from G.A. Berry, Glasgow to D.C. D’Eath, 16 July 1930 and 18 July 1930.

${ }^{33}$ Lewis Johnman and Hugh Murphy, 'An Overview of the Economic and Social Effects of the Interwar Depression on Clydeside Shipbuilding Communities', International Journal of Maritime History, 28, 1 (2006), $241-2$.

${ }^{34}$ J.J. Smyth, Labour in Glasgow, 1896-1936: Socialism, Suffrage and Sectarianism (East Linton, 2000), 22-23.

${ }^{35}$ John M. MacKenzie, 'The Second City of the Empire': Glasgow - imperial municipality', in Felix Driver and David Gilbert (eds), Imperial Cities (Manchester, 1999), 221-22.
} 
Unemployment, even among skilled workers, was a severe problem even before the Great Depression and 'hit with a vengeance' by $1930 .{ }^{36}$ In Scoutstoun, the shipbuilding firm Charles Connell closed that year and did not reopen until 1938. The industry was decimated and tonnage produced by Clyde shipyards hit the lowest levels since 1860 in 1932, a year in which $77 \%$ of all insured shipbuilding workers across Scotland were out of work. ${ }^{37}$ This was the fate the riveters sought to escape.

The riveters were not only single men though. Mrs Daly, the wife of one of the riveters, explained that her husband went overseas as he had been laid off a year ago and had been unable to find work in Glasgow since:

One day he [Joseph Daly] came home full of enthusiasm over a scheme he had heard about. Some of his mates had told him that there was a chance of getting work that would suit him in South Africa. I was not keen on his going so far away, but he was tired of looking for work and we have three young children to consider so, after a talk, I suggested he should make further inquiries.

He went out one morning soon afterwards and came back home full of the new good news. He had made inquiries and had seen a representative of a firm that was requiring the men. It was apparently the chance of a lifetime. He would be able to earn at least $£ 710$ s a week, and the money to pay his fare out to South Africa would be advanced. ${ }^{38}$

Joseph Daly had to provide for the family, and his wife had to make sure what was provided was enough for the family. This was 'a rule understood by both males and females as the norm' and a 'widespread understanding between many husbands and wives' on Clydeside in the interwar period according to Hugh Hagan. ${ }^{39}$ With no work in Glasgow, Joseph Daly was unable to provide, and so it was natural so look overseas.

Although the Daly's were apparently unsure exactly where the Copperbelt was located, many aspects of life there would have been familiar to anyone with a decade or so of experience working on the Clyde, as he did. One of these aspects was the colour bar, the perception that there was a link between maintaining racial segregation on the job and establishing decent pay and working conditions. On

\footnotetext{
${ }^{36}$ Johnman and Murphy, 'Clydeside Shipbuilding Communities', 244.

${ }^{37}$ Johnman and Murphy, 'Clydeside Shipbuilding Communities', 245-6.

38 'Clyde workmen's return from South Africa', Glasgow Weekly News, 28 November 1930.

${ }^{39}$ Hugh Hagan, '"It's My Job to Work and It's Yours to Make it Go Round:" The Experience of Shipyard Workers' Wives in Port Glasgow between the Wars', International Journal of Maritime History, 28,1 (2006), 309. The woman who told Hagan this was herself married to a riveter.
} 
Clydeside, severe job competition following the First World War had intensified the campaign against the employment of Chinese and black sailors. Non-white sailors were hired on lower-paid contracts and maritime trade unions had responded by attempting to exclude them from the shipping industry. This culminated in a riot by white sailors in January 1919, only a few days before the more famous George Square riot. ${ }^{40}$

Prominent figures from Glasgow's labour movement supported the colour bar and both Willie Gallacher and Emanuel Shinwell were involved in the seamen's campaign and linked it to the struggle for a 40hour week. Shinwell, in particular, identified Chinese sailors as the cause of white British unemployment. ${ }^{41}$ This riot was part of wider wave of unrest in British ports from 1919 to 1921 in which white working-class rioters targeted Arabic, black and Chinese sailors and their communities. ${ }^{42}$ These riots were successful. They discouraged shipping companies from hiring black and Chinese labour and many of these sailors already in British ports were repatriated by the British Government. ${ }^{43}$

\section{The Copperbelt in 1930}

Another pertinent reason why the mining companies had to reach out internationally to recruit skilled labour was that the Copperbelt mining camps had already become notorious in mining centres in southern Africa. Miners with prior knowledge of conditions on the mines were reluctant to work there. Most of the European workforce lived in single-room buildings with thatched roofs known as rondavels that leaked in the rain, in kator huts with corrugated iron walls and roofs which were deafening in the rain or in boarding houses. ${ }^{44}$

Life in the boarding houses was rough. Jean Watson, who had arrived from Aberdeen via a Southern Rhodesian gold mine to run a boarding house, remembered her residents as tough customers, who carried guns with them everywhere and frequently had to be extricated from fights. Watson claimed that she did not want to get off the train when she first saw the Copperbelt, especially after she found

\footnotetext{
${ }^{40}$ Jacqueline Jenkinson, 'Black Sailors on Red Clydeside: Rioting, Reactionary Trade Unionism and Conflicting Notions of 'Britishness' Following the First World War', Twentieth Century British History 19, 1, (2008), 33-36. However, there is some evidence that the Clydeside labour movement also forged progressive international links, alongside this racialized hostility. See Paul Griffin, 'Labour struggles and the formation of demands: The spatial politics of Red Clydeside', Geoforum, 62 (2015), 121-30.

${ }^{41}$ Jenkinson, 'Black Sailors', 34-35, 38.

42 Jacqueline Jenkinson, Black 1919: Riots, Racism and Resistance in Imperial Britain (Liverpool, 2009 ), 1, 72.

${ }^{43}$ Jenkinson, 'Black Sailors', 56-57 and Jenkinson, Black 1919, 155-82.

${ }^{44}$ Lewis Gann, A History of Northern Rhodesia: Early Days to 1953 (London, 1964), 209.
} 
out that the large group of men waiting on the platform were not there to greet her, but to make sure the latest consignment of whiskey had arrived intact. Others had a similar first impression, as Watson recalled:

taking one poor lad - he had just come out from England - to the Kator hut he had to share with some of the drillers. We opened the door and there were four men, playing cards by candlelight. Each had a bottle of whisky and a gun on the table. The poor laddie wanted to leave the next day! $!^{45}$

The white workforce attracted to such camps was described as 'human flotsam' who 'usually left for reasons other than the completion of work' by Lucy Cullen, Roan Antelope's sharp-tongued, New Yorker secretary. ${ }^{46}$ She was right that white mineworkers were prone to abrupt departures but this was often because they had little stability or job security after travelling hundreds or thousands of miles to reach the Copperbelt. Miners often had to borrow money from the companies to pay for their journey and had to buy equipment such as helmets from the mine, or bring their own, so could easily end up in debt to the company. ${ }^{47}$

White mineworkers were, in theory, dependent on the company. Most were daily-paid and could be sacked with 24 hours' notice, a threat which one miners' wife at nearby Nchanga Mine described as hanging 'like the sword of Damocles over their heads' ${ }^{48}$ This threat was not always effective. A man who had worked at the smelter at Bwana Mkubwa Mine recounted the story of one man who was fired on the spot for stealing, but refused to leave and kept turning up for work. Eventually, the company manager gave up trying to get rid of him and let him continue working. ${ }^{49}$ The riveters were also hired as daily-paid workers, a situation which would have been familiar to them as an informal daily market operated on the Clyde during the interwar years for boilermakers not on contract to be hired for a day's work. ${ }^{50}$

The real notoriety of the camps was caused by disease, however. Both European and African workers in the region avoided Roan Antelope because there was such a heavy death toll on the mines in the late

\footnotetext{
45 'Guesthouse Triumvirate', Horizon, March 1959.

${ }^{46}$ Cullen, Beyond the Smoke, 335.

${ }^{47}$ ZCCM 16.2.4B, Pamphlet of information for employees proceeding to N. Rhodesia, Roan Antelope Copper Mines, [undated].

${ }^{48}$ Winifred Tapson, Old Timer (Cape Town, 1957), 158.

49 '30 years' service', Rhokana Review, March 1956.

${ }^{50}$ McKinlay and Hampton, 'Making Ships, Making Men', 23.
} 
1920s. ${ }^{51}$ Irwin himself recalled that, in 1928, it was not unusual to have almost one-third of the European workforce at the mine unable to report for work at any one time due to malaria or other tropical diseases, which were so common they were referred to as 'Roanitis'. Medical services were rudimentary at best and before a hospital was constructed in mid-1930, the camp doctor performed surgery on a kitchen table in a corrugated iron hut. ${ }^{52}$ Tales about camp conditions spread widely in southern Africa. On arrival in Cape Town, the riveters would have encountered railway staff who delighted in telling those heading to the Copperbelt that it was a waste of money buying a return ticket, they would never make it back alive! $!^{53}$

Efforts to eradicate malaria were underway by mid-1930 but had made little impact by the time the riveters arrived. Within two weeks of arriving, Joseph Daly complained in a letter to his wife that he had already been in hospital with septic poisoning and other diseases lurked round every corner:

I would never think of bringing you here. You would never stick it. Mind you, there are worse places than Dalmuir! You don't get snakes, ants, jiggerfleas, tsetse flies, sunstroke, malaria, dysentery, and blackwater fever there. The sun to-day is 102 degrees in the shade, and it is only what we get every day! $!^{54}$

Death rates remained high until the early 1930s and Jean Watson's husband, a miner at Roan Antelope, died in $1931 .{ }^{55}$ A member of the Ross Institute for Tropical Diseases, Malcolm Watson, visited the Copperbelt between April and June 1930 and calculated that the death rate among the European population at Roan Antelope was higher than the death rate in England and Wales between 1871 and $1880 .{ }^{56}$ The whole area, the riveters later claimed, was termed 'the Valley of Death' by local Africans. ${ }^{57}$

Death certainly was common and it appears that little sentimentality was attached to it. Funeral services at Roan Antelope were performed by the bartender as he had 'a very pleasing voice' and there were no

\footnotetext{
${ }^{51}$ Lyn Schumaker, 'Slimes and Death-Dealing Dambos: Water, Industry and the Garden City on Zambia's Copperbelt', Journal of Southern African Studies, 34, 4 (2008), 824-25.

52 D.D. Irwin, 'Early Days on the Copperbelt', The Northern Rhodesia Journal, VI (1965), 113.

${ }^{53}$ Malcom Watson, African Highway. The Battle for Health in Central Africa (London, 1953), 4.

54 ‘Clyde workmen's return from South Africa’, Glasgow Weekly News, 28 November 1930.

55 'Guesthouse Triumvirate’, Horizon, March 1959.

${ }^{56}$ The death rate was around twenty-four per thousand at Roan Antelope in 1929 and 21.4 in England and Wales in 1871-1880 according to Watson. Watson, African Highway, 30.

57 'Glasgow trade union sensation - Clyde workers adventure', Glasgow Sunday Mail, 21 December 1930.
} 
clergy at the camp. ${ }^{58}$ Few clergy, it seems, were required in any case. Indeed, a local magistrate and devout Christian complained that, at the time, the Copperbelt was 'frankly, with a few exceptions, a purely material, pagan centre. Few of the whites practised Christianity'. ${ }^{59}$

\section{Riveters at Roan Antelope Mine}

There were no trade unions among either the European or the African workforce in 1930 and the mines had little experience of labour troubles, though there appears to have been a brief stoppage by African workers at Roan Antelope in September 1927. ${ }^{60}$ The mine management were initially somewhat complacent that the arrival of riveters from Clydeside would alter this situation, despite being aware of the region's radical reputation. Irwin himself noted that he was aware 'that the Scotch shipyards had a rather strong red tinge,' but 'good rivetters [sic] are usually a bit wild and wooly anyway' ${ }^{61}$

A 'red tinge' may have been an understatement. One of the riveters who travelled to nearby Nkana Mine, Charles Forrestor, had visited the Soviet Union as a delegate of his shipyard in 1929. Notably, Forrestor already had experience of fomenting trouble on the international circuits of white labour. $\mathrm{He}$ had worked briefly in Canada from 1925 to 1926 before being deported for his involvement in a demonstration. ${ }^{62}$ Several of the other men were active trade union members. Three riveters - Joseph Daly, David Sillars, and Robert Brown - had all been in discussions with trade unions in Glasgow about what approach to adopt on the Copperbelt prior to their departure, as they were all members of the United Society of Boilermakers, Shipbuilders and Structural Workers. ${ }^{63}$

It did not take long for this approach to become apparent. The riveters arrived in early October 1930, and before the end of the month had formed a committee to represent the many grievances of all Glaswegian riveters on the mine. The men claimed that they had been promised significant overtime

\footnotetext{
${ }^{58}$ Irwin, 'Early Days', 113.

${ }^{59}$ Frank Melland, African Dilemma (London, 1937), 79.

${ }^{60}$ John Garber Philips, 'Roan Antelope: Big Business in Central Africa 1890-1953', Ph.D. thesis, University of Cambridge, 2000, 170-71.

${ }^{61}$ ZCCM 16.2.4B, Letter No. 448, 8 November 1930.

62 'Election Echo court story of row at meeting', Glasgow Evening Citizen, 26 January 1932.

${ }^{63}$ ZCCM 16.2.4B, Letter from G.A. Berry to D.C. D’Eath, 31 December 1930. On a related note, this would bolster Nicholas Evans claim that membership of trade unions functioned as information channels informing male migrants of opportunities that existed overseas, Evans, 'Emigration of skilled male workers', 273-4.
} 
when recruited and since this was lacking, demanded an immediate pay increase to 28/- a shift. ${ }^{64}$ Others on the mine, they charged, were receiving this wage for doing the same kind of work.

The construction superintendent in charge of the riveters was George Neville, from Douglas, Arizona, who had previously overseen smelter construction at Copper Queen Mine, at the same time as Irwin was superintendent at the mine. ${ }^{65}$ The immediate instinct of these American managers was to resist any move towards trade unions and collective bargaining. Copper mining companies had fought hard to successfully keep trade unions out of the mines and smelters in the American West in previous decades. Throughout the 1920s, unions had been unable to gain a substantial foothold in the copper industry in Michigan, Arizona, Utah, or Nevada. ${ }^{66}$ Mine managers were not about to let this happen on the Copperbelt. Even though they had intended to increase the riveters pay to 28/- as they were impressed with the quality of the work, as soon as the men asked for this themselves, 'we felt that it was best to concede nothing', ${ }^{67}$

The riveters formulated a decisive response to this refusal a few days later. On 11 November, almost all the riveters gave 24 hours' notice that they were leaving, but decided not to bother working out this perfunctory notice period and walked off the job. 24 hours' may have seemed like an unnecessarily onerous notice period, on the Clyde shipyards the standard notice for imminent unemployment was one hour. ${ }^{68}$ Two riveters did not hand in their notice though; one because he was in jail after getting into a fight in the mine township, while the other man had already vanished. The mystery of the missing riveter Fred Venman was not solved until three days later, when he returned to work, explaining to the foreman that he had been hiding until the others had left. He wanted to stay and assumed they would have beaten him up for staying at the job. ${ }^{69}$

\footnotetext{
${ }^{64}$ ZCCM 16.2.4B, Telegram from General Manager, Roan Antelope to Selection Trust London, 31 October 1930.

65 'Mining and metal news', Engineering and Mining Journal, 123 (1927), 223.

${ }^{66}$ Charles K. Hyde, Copper for America: The United States Copper Industry from Colonial Times to the 1990s
} (Tucson, 1998), 149-59, 86.

${ }^{67}$ ZCCM 16.2.4B, Letter No. 448, 8 November 1930.

${ }^{68}$ Johnman and Murphy, 'Clydeside Shipbuilding Communities', 238.

${ }^{69}$ ZCCM 16.2.4B, Letter No. 450, 22 November 1930. Venman's decision to stay may have been influenced by the fact he had already emigrated from Glasgow to Canada twice in search of better prospects, see UK, Outward Passenger Lists, 1890-1960 (http://search.ancestry.com/search/db.aspx?dbid=2997: accessed on 9 October 2014), Record of Fred F. Venman, 21 June 1913 and 3 August 1923. 
It was perhaps less the threat of violence that encouraged the rest to leave together than a sense of solidarity and an appreciation of working practices on the Clyde. Apparently several of the riveters saw their foreman before departing 'and said that they were really sorry to leave, but that it was necessary according to their belief in sticking together'. If they didn't stick together 'they felt that they could never work with their pals on the Clyde again' ${ }^{70}$ As noted previously, riveters worked in gangs on the Clyde shipyards and could face even greater difficulties finding work if they defied the decision of the majority and 'their pals' subsequently refused to work with them.

\section{Riveters at Nkana Mine}

In a piece of extraordinarily poor timing - at least, from the companies' point of view - a second set of nine riveters from Govan, Glasgow arrived at nearby Nkana Mine at the same time as riveters at Roan Antelope decided to quit. ${ }^{71}$ This second group of men made their assessment of the prevailing conditions at Nkana and what to do about it even more rapidly. They discovered that riveters at Roan Antelope were refusing to work and that others at Nkana were being paid more than the riveters agreed contract rates. This was a point of principle, the men later reported, 'we know that we, as members of the Trade Union, had to get the rate of pay being paid to all other Tradesmen on the mine'. Within one day, the riveters concluded they had been brought out from 'the Clyde with a view to breaking down the wages of the men,' and demanded a meeting with the management. ${ }^{72}$

The management structure at Nkana had a similar international composition to Roan Antelope. Directly in charge of the riveters was the American construction engineer Alma Ek, who had been recruited from the Braden Copper Company in Chile. ${ }^{73}$ Ek's superior was a Scot, Archie Morton, who had begun his working life in Edinburgh, but left for New Zealand in 1909 and eventually found his way to the copper mines of British Columbia. He joined Nkana as resident engineer in early 1930 following an invitation from Bancroft. ${ }^{74}$

The complaints about economic exploitation brought to these managers by the riveters were closely bound up with racism. On their return to Glasgow, the men complained both that they were paid less than American and Australian workers on the mine and about their poor living conditions, including

\footnotetext{
${ }^{70}$ ZCCM 16.2.4B, Letter No. 450, 22 November 1930. American South Africa.

${ }^{72}$ ZCCM 16.2.4B, Report of men from N'kana mine, [undated].

${ }^{73}$ Bancroft, Mining in Northern Rhodesia, 158-9.

74 ‘An old timer retires', Rhokana Review, September 1952.
}

${ }^{71}$ ZCCM 16.2.4B, Extract from a report dated 3 December 1930 by L.A. Pollock, Joint Managing Director Anglo- 
the claim that the 'only food they could secure was the same as that dished out [to] the colour labour, namely curried rice'. Both of these were claims that they were not being treated in the same way as other 'white men' on the mine. ${ }^{75}$

The politics of white labourism became more apparent at the meeting with the mine manager Arno Winther. The men, including Charles Forrestor, were adamant that only members of their union should be doing boilermakers' work and this was the only work they should be doing. African workers should not be doing any part of this work and they would not train Africans to do this work. In his reply, the men claimed that Winther 'stated that in all open work they intended to use Native labour until such time as they learn the machine fully... We then asked if we were expected to teach these natives the machine and was told yes' ${ }^{76}$ It is likely that Winther told them exactly that as training Africans to take over more semi-skilled work was the policy of both RST and RAA at this time, primarily because African labour was substantially cheaper. ${ }^{77}$

Since Winther refused to release them from their contract, the riveters went to the local police post to have themselves declared Undesirable Immigrants, meaning that the colonial administration would deport them. Unsurprisingly, they had little difficulty securing this status and left Nkana on 15 November. ${ }^{78}$ Their career at Nkana Mine lasted precisely one day. At the same time, 15 miners from northern England walked off the mine and returned to England, a move partly related to dissatisfaction with their own conditions and partly in solidarity with the riveters. ${ }^{79} \mathrm{~A}$ colonial official later concluded that RAA made 'a serious mistake' not only in bringing the men in on lower rates of pay but also by bringing all the men out on the same boat as 'they had constituted themselves a trade union group before they ever entered the territory'. ${ }^{80}$

\footnotetext{
75 'Glasgow trade union sensation - Clyde workers adventure', Glasgow Sunday Mail, 21 December 1930.

${ }^{76}$ ZCCM 16.2.4B, Report of men from N'kana mine, [undated].

${ }^{77}$ See Berger, Labour, 48 for the training of African workers at Nkana and see ZCCM 12.2.10C, Letter from David Irwin to A.D. Storke, 1 April 1932 for a general statement of policy on training Africans for semi-skilled work from Roan Antelope. Construction engineer George Neville is listed here as one of the managers endorsing this policy.
}

${ }^{78}$ ZCCM 16.2.4B, Affidavit from Arno S. Winther, 20 November 1930.

${ }^{79}$ ZCCM 16.2.4B, Extract from a report dated 3 December 1930 by L.A. Pollock, Joint Managing Director AngloAmerican South Africa.

${ }^{80}$ ZNA SEC3/48, Confidential Memorandum on Immigration Policy and the Field of European Employment at the Mines in Northern Rhodesia, [undated]. 
Their abrupt departure was not the end of the problems these men caused for Anglo American though. Several days later, the men arrived drunk and penniless at the Alexandra Hotel in Cape Town, where they proceeded to riot. Over three days, the men broke $£ 43$ worth of furniture and windows then, in a final altercation on the way out of the hotel, some of the men tore the trousers of the hotel porter. One of the men, John Currie, had managed to get arrested and imprisoned during his brief stay in the city. The others were kept under guard at the hotel until they boarded the ship. ${ }^{81}$

\section{Aftermath}

Incredibly, this disastrous experience did not dissuade either RST or RAA from further overseas recruitment of white workers, a practice that only really faded out in the early 1970s. RST's London office wrote to George Berry in December 1930 to request the contact details for the trade union these men belonged to. The company wanted to counteract the spread of any adverse information which would prevent Roan Antelope from recruiting in Scotland and northern England in the future. ${ }^{82}$ Berry advised them not to bother, as the local secretary of the Boilermakers' Society was 'very red' ${ }^{83}$

This request was likely motivated by the fact that both groups of riveters has pushed trade unions in Glasgow to organize a public meeting to air their grievances and to push for action against the mining companies. ${ }^{84}$ Local trade unionists lobbied Labour MP for Glasgow Partick Adam McKinlay on behalf of the riveters and secured a local solicitors firm to press their case. ${ }^{85}$ To the astonishment of Roan Antelope, who maintained that the riveters had left the mine owing the company $£ 1,093,18$ of them had the audacity to sue the company for misrepresentation of contract and unpaid wages. ${ }^{86}$

Nothing appears to come of this attempt, presumably as the men had proceeded on relatively shaky legal ground. However, the story of the brief but chaotic trip of the riveters may have, in some ways, encouraged white labour migration to the Copperbelt by effectively advertising what the prevailing conditions on the Copperbelt were like. For instance, a newspaper in the Australian mining town of

\footnotetext{
${ }^{81}$ ZCCM 16.2.4B, Letter from Fred Bartlett, Rhodesia Chartered Agency to T. Hamilton, Immigration Department, Livingstone, 25 November 1930.

${ }^{82}$ ZCCM 16.2.4B, Letter from D.C. D’Eath to George A. Berry, 22 December 1930.

${ }^{83}$ ZCCM 16.2.4B, Letter from G.A. Berry to D.C. D’Eath, 31 December 1930.

84 'Glasgow trade union sensation - Clyde workers adventure', Glasgow Sunday Mail, 21 December 1930.

${ }^{85}$ ZCCM 16.2.4B, Letter from A.S. McKinlay MP to Secretary, Roan Antelope London, 4 February 1931.

${ }^{86}$ ZCCM 16.2.4B, Statement of Rivetters Accounts, [undated] and letter from Andrew Aitkin to Secretary, Roan
} Antelope London, 20 April 1931. 
Broken Hill reported the incident, but notably did so under the headline '£55 a month in Rhodesia' and the story was covered in the British press. ${ }^{87}$

The maelstrom of alcohol and low-level violence these men inhabited was not greatly different to the society they encountered in the Copperbelt's mining camps. More pertinent though, is what else was similar. For the riveters, sticking to trade union principles and not accepting less than the rate for the job was as important in a mining camp in the middle of Africa as it was on the Clyde. The traditions of the trade, 'traditions of self-respect based on hard, physical work and a determination to be paid their worth', had to be maintained on the Clyde and away from it. ${ }^{88}$ These principles and traditions had to be adhered to even when it meant hardship and considerable personal inconvenience. It meant traveling several thousand miles back to life on the dole in Glasgow rather than accepting two shillings less a day on the Copperbelt.

These men saw themselves as a part of an international working class and they would not undercut the established rates of pay and working conditions of American, Australian and British miners already working there. The limits to this solidarity were clearly racial limits. At both Roan Antelope and Nkana Mine, the 'black squad' demanded to be treated the same as other white workers on the mine, the only relevant comparison for them. Like other white workers on the Copperbelt at this time, they saw that the wages and conditions of African workers as none of their business, other than as something to avoid for themselves. The riveters bristled at being treated in any way like the African workforce and denounced the companies' intentions as nothing more than 'white slavery' ${ }^{89}$

This was another episode in the transnational world of white labour: hard-bitten American mine managers clashing with Glaswegian riveters in southern Africa. Both drew on their experiences elsewhere in this world, maintained a decidedly international outlook and saw profound similarities between the Copperbelt and industrial centres elsewhere in the world. When skilled workers were required for a specific job, distance was no obstacle and they could be recruited from thousands of miles away. When men couldn't find work in Glasgow and work was available elsewhere, distance was again major concern and if the situation there was not to their satisfaction, they would down tools and return immediately.

Trade unions in Glasgow supported the men's actions and gave no indication that they should have acted differently in any way. There is no evidence of any direct link between those involved in the

87 '£55 a month in Rhodesia’, Barrier Miner, 15 June 1931. The Barrier Miner article is mostly a reprint from the London Daily News.

${ }^{88}$ McKinlay and Hampton, 'Making Ships, Making Men', 28.

${ }^{89}$ ZCCM 16.2.4B, Report of men from N'kana mine, [undated]. 
campaign to prevent non-white sailors from working in Glasgow and the riveters who went to the Copperbelt a decade later. However, it would be remarkable if this context on Clydeside did not influence demands to prevent Africans doing skilled riveting work on the Copperbelt. These demands were not separate from the opposition of these men towards exploitation or from the trade union principles they espoused. The working class they saw themselves as part of simply did not include Africans.

Despite the shortness of their stay on the Copperbelt, these men's actions foreshadow major themes in the history of the region, particularly the connection between maintaining key principles such as the rate for the job and excluding cheaper African labour from these jobs..$^{90}$ The brevity of their stay, however, underlines the international and not the local origin of these ideas and practices. The miners who came to the Copperbelt did not pick these ideas up on arrival, they brought them with them. In turn, the riveters may have taken ideas about the Copperbelt back to Glasgow as there is subsequent intriguing connection between the Clyde and the Copperbelt. A decade later when leaders of the white mineworkers' union were arrested and deported during the Second World War, virtually every MP who supported them and spoke up for them in Parliament was, or had been, a Clydeside radical. ${ }^{91}$

The riveters' departure from the Copperbelt was soon followed by thousands of others. The optimism of the early years of the region was dashed by the dramatic slump in copper prices prompted by the global economic depression. The copper industry contracted sharply and, beginning in February 1931, mines began to shut all across the Copperbelt, sacking virtually all their workforce, often at a few hours' notice, when they did. Roan Antelope and Nkana were the only mines that remained open during this period but both halted construction work and curtailed production in $1931 .{ }^{92}$ Following the same international routes of white labour the riveters had travelled along from Glasgow, white mineworkers dispersed across the globe in search of work.

\footnotetext{
${ }^{90}$ Butler, Copper Empire, 56-59.

${ }^{91}$ These MPs included Willie Gallacher, David Kirkwood and James Maxton. See Parliamentary Debates (Commons), 383, 21 October 1942, 1954-56 for a good example of their intervention.

I have written about these wartime disputes in 'The World of European Labour on the Northern Rhodesian Copperbelt, 1940-1945', International Review of Social History, 60, 2 (2015), 225-55.

${ }^{92}$ Berger, Labour, 20.
} 